\title{
НЕФТЕХИМИЧЕСКАЯ ПРОМЫШЛЕННОСТЬ КАК ДРАЙВЕР РАЗВИТИЯ НЕМАТЕРИАЛЬНОЙ СОБСТВЕННОСТИ
}

\section{(c) 2019 Колесникова Юлия Сергеевна}

кандидат экономических наук, доцент кафедры управления человеческими ресурсами Казанский (Приволжский) федеральный университет, Респ. Татарстан, Казань

E-mail:hulia_k@mail.ru

\section{(c) 2019 Мокичев Сергей Дмитриевич}

кандидат экономических наук, доцент кафедры экономической теории и эконометрики Казанский (Приволжский) федеральный университет, Респ. Татарстан, Казань

E-mail: mokichev.kpfu@mail.ru,

\section{(c) 2019 Мухаметшин Дамир Фаридович}

кандидат экономических наук, доцент кафедры управления человеческими ресурсами Казанский (Приволжский) федеральный университет, Респ. Татарстан, Казань

E-mail: DFMuhametshin@kpfu.ru

В статье рассмотрено распределение нематериальных активов по регионам и федеральным округам. Проанализированы данные по патентованию и использованию объектов интеллектуальной собственности в регионах РФ. Исследована структура балансов компаний с наиболее дорогими брендами, среди которых в РФ присутствуют предприятия нефтегазодобывающей и перерабатывающей промышленности. Сделан вывод, что нефтедобывающая промышленность выступает катализатором развития нематериальной собственности в регионах РФ.

Ключевые слова: нематериальные активы, нематериальная собственность, нефтедобывающая промышленность, патент, лицензия.

В условиях развития информационного общества конкурентные преимущества достигаются благодаря нематериальным ресурсам, ввиду чего права собственности на них приобретают особую значимость, позволяют специфицировать данные ресурсы и обеспечивать конкурентоспособность на рынке в долгосрочном периоде.

По данным независимой оценки Brand Finance самыми нематериальными отраслями в мире стали в 2018 г.: реклама, фармацевтика, косметическая, продукты, СМИ, напитки, программное обеспечение и интернет. Самыми нематериальными нациями являются: французы, итальянцы, бельгийцы, немцы и португальцы. Россияне, по оценке Brand Finance, входят в рейтинг, но находятся в конце списка, соседствуя с индийцами, перуанцами и киприотами [1].

Объектами нематериальной собственности выступают патенты, лицензии, ноу-хау, репутация, социальный капитал, связи с клиентами и потребителями и др. Категория интеллектуальная собственность, закрепленная в Гражданском кодексе РФ не покрывает полностью все объекты нематериальной собственности. Объекты созданные стихийно, немыслительными усилиями, как, например, имидж, сформированный под воздействием третьих лиц, не может в полной мере считаться объектом интеллектуальной собственности, но является объектом нематериальной собственности. Коммерциализированными объектами нематериальной собственности выступают нематериальные активы и репутация предприятия, которые единственные дают нам количественную оценку нематериальной собственности.

На долю нематериальных активов в РФ в структуре активов компаний приходится в период с 2013-2017 гг. не более 0,003 [2]. Динамика нематериальных активов представлена на рис. 1 .

Распределение нематериальных активов по регионам РФ также неоднородно. Около половины нематериальных активов сконцентрировано в Центральном федеральном округе, в частности в г. Москва, далее следуют Северо-Западный, Приволжский и Уральский федеральные округа (рис. 2).

Нефтяные и газовые бренды по данным 


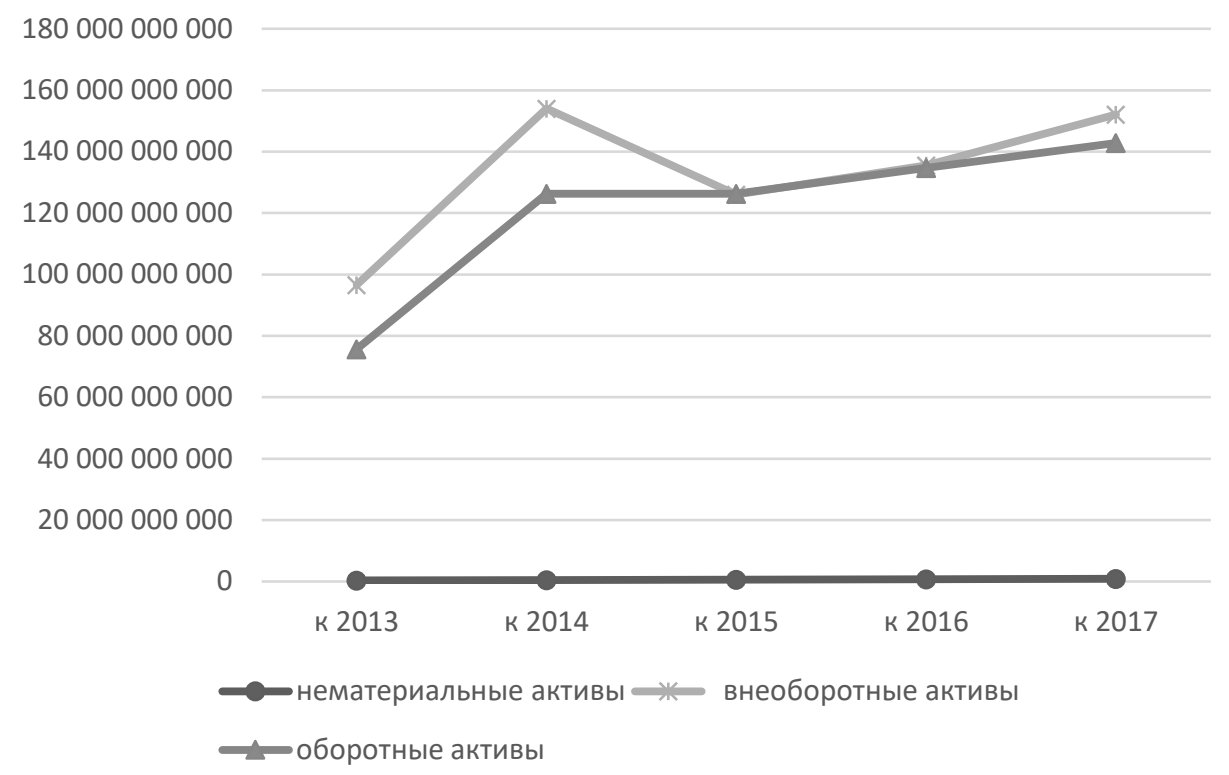

Puc. 1. Динамика активов в РФ [2]

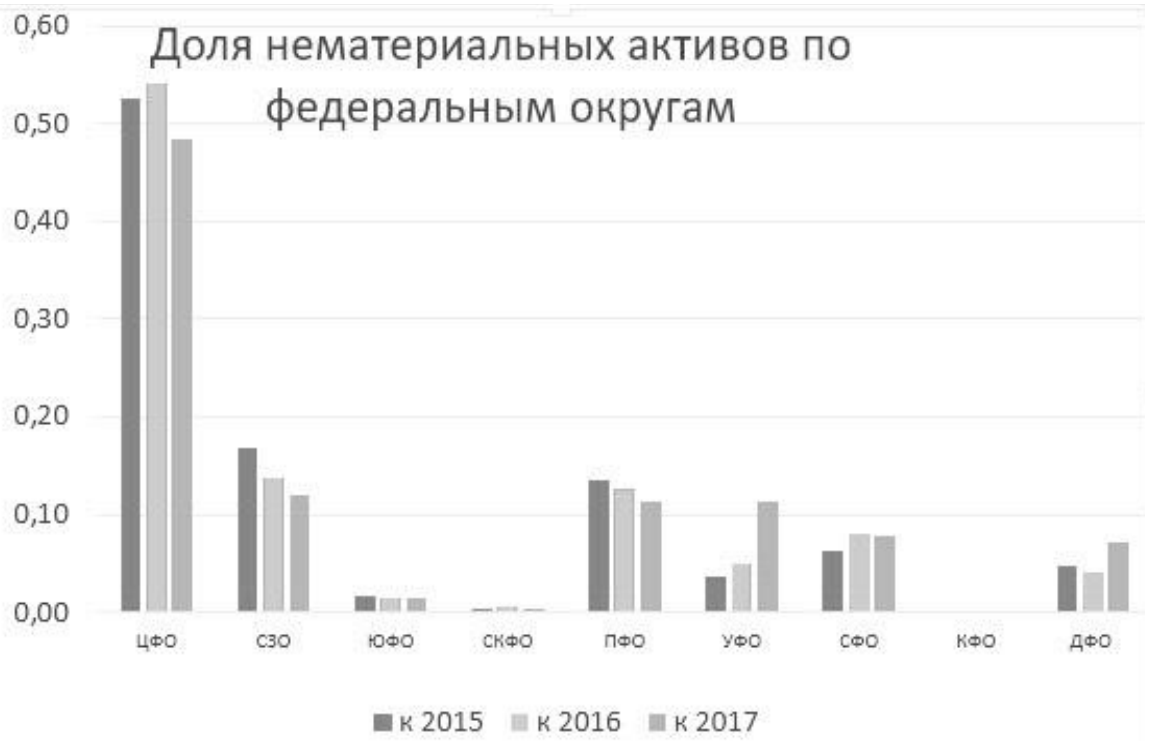

Puc. 2.Доля нематериальных активов по федеральным округам [2]

Brand Finance вошли в топ 4 из 10 брендов, такие как Газпром, Лукойл, Роснефть и Татнефть. Мы проанализировали структуру балансов самых дорогих российских и мировых брендов по версии Interbrand. Нефтегазодобывающие компании лидируют по показателю нематериальных активов в абсолютном выражении, что объясняется высокой стоимостью активов данных компаний, нематериальные активы Газпрома превышают 19 млрд. руб. в 2019 г. [3] При этом доля нематериальных активов в структуре ба- ланса данных компаний не велика, так, например, суммарная доля нематериальных активов и репутации Газпрома, Татнефти, Роснефти не превышает 1\% от общего объема активов. В основном нематериальные активы в нефтегазодобывающих компаниях представлены правами на объекты интеллектуальной собственности (патенты). Татнефть занимает первое место в Республике Татарстан по количеству патентов. Кроме того, в структуре отчетности нефтегазодобывающих компаний появляется показа- 
тель - нематериальные поисковые активы к которым относят права пользования недрами и лицензии на геологическое изучение и добычу. Данный показатель интересен для изучения при исследовании объектов нематериальной собственности и в тоже время не отражает по своей сущности объекты интеллектуальной собственности.

Наибольшую долю нематериальной собственности в структуре активов в 2017 г. среди компаний, обладающих наиболее дорогим брендом, имели Балтика, Сбербанк, Mail.ru. Отличием нематериальной составляющей данных компаний является наличие репутации и брендов в структуре активов, а не патентов и лицензий, как у нефтегазодобывающих компаний. Общей тенденцией и для РФ, и для зарубежных стран является наличие производителей товаров массового потребления и производителей IT технологий среди наиболее нематериальных компаний. Особенностью РФ является присутствие среди наиболее нематериальных компаний представителей банковского и нефтегазодобывающего сектора.

По данным Роспатента об использовании результатов интеллектуальной деятельности по видам экономической деятельности наиболь- ший показатель по использованию интеллектуальной собственности у организаций, занятых образованием, производством машин и оборудования и добычей сырой нефти и природного газа [4].

При анализе использования результатов интеллектуальной собственности в разрезе регионов, где данный показатель превышает среднее значение по федеральному округу, то мы видим, что среди лидеров оказываются г. Москва и Московская область, г. Санкт-Петербург, Республика Татарстан, Нижегородская область, Пермский край, Свердловская и Тюменская область, Красноярский край.

На рис. 2 проанализировано распределение нематериальных активов по федеральным округам, если рассмотреть регионы, лидирующие по объему нематериальных активов в абсолютном выражении, то среди них окажутся г. Москва и Московская область, г. Санкт-Петербург, Иркутская, Тюменская, Самарская и Челябинская области, Республики Татарстан и Башкортостан.

Среди лидеров по нематериальным активам оказались «столичные субъекты», где велика концентрация организаций и активов в целом и нефтегазодобывающие регионы. На рис. 3 представлена карта распределения добычи нефти в

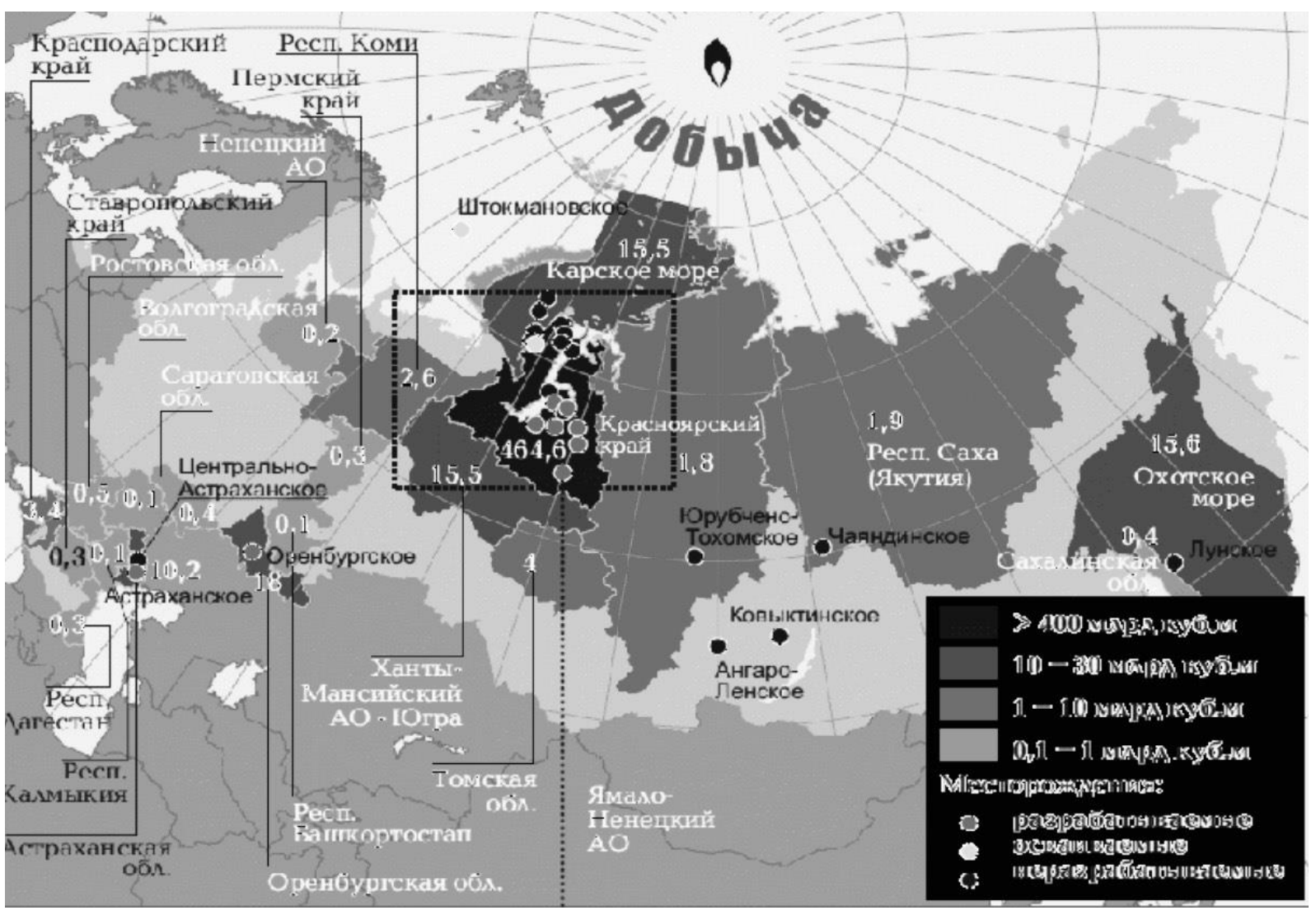

Puc. 3. Распределение добычи нефти по субъектам РФ [5]. 
Таблица 1. Рейтинг регионов РФ по развитию нематериальной собственности за 2016 г. [7]

\begin{tabular}{|c|l|c|}
\hline $\begin{array}{c}\text { Номер в рейтинге } \\
\text { за 2016 г. }\end{array}$ & \multicolumn{1}{|c|}{ Рейтинг регионов } & Значение \\
\hline 1 & г.Москва & 0.342815949 \\
\hline 2 & Чукотский авт.округ & 0.234093574 \\
\hline 3 & г.Санкт-Петербург & 0.220871058 \\
\hline 4 & Московская область & 0.210750054 \\
\hline 5 & Магаданская область & 0.198645686 \\
\hline 6 & Сахалинская область & 0.183843033 \\
\hline 7 & Тюменская область & 0.181569211 \\
\hline 8 & Иркутская область & 0.180282723 \\
\hline 9 & Камчатский край & 0.179971302 \\
\hline 10 & Республика Саха (Якутия) & 0.165656961 \\
\hline
\end{tabular}

РФ, где среди лидирующие позиции занимают Ханты-Мансийский и Ямало-Ненецкий автономные округа, Республики Татарстан и Башкортостан, Сахалинская, Самарская, Тюменская области.

Нами разработана модель развития нематериальной собственности в регионах РФ, которая позволила составить рейтинг регионов, который представлен в таблице 1 [6].

Таким образом, регионы с высокими показателями добычи нефти оказываются среди лидеров по объему нематериальных активов. В Ямало-Ненецком, Ханты-Мансийском автономных округах, Омской и Новосибирской области высокие относительные показатели нематериальных активов, т.е. доля нематериальных акти- вов в структуре активов региона.

Данный факт позволяет говорить о том, что нефтедобывающая промышленность выступает катализатором развития нематериальной собственности в регионе. Показатели развития нематериальной собственности также оказались выше в столичных и в нефтедобывающих регионах. Нами были определены коэффициенты опережения развития нематериальной собственности в регионах с нефтедобывающей промышленностью они колеблются от 1,16 до 1,8. Определено, что для обеспечения конкурентоспособного положения региона на 1 руб. ВРП должно приходиться 0,03 руб. нематериальных активов.

\section{Библиографический список}

1. Ежегодный обзор стоимости нематериальных активов в мире Brand Finance. Режим доступа: Acrobat Reader. URL: http://brandfinance.com/images/upload/gift_report_2018_for_print.pdf(дата обращения: 09.02.2019)

2. Составлено авторами на основе данных Росстата. URL: https:/www.fedstat.ru/indicator/37175 (дата обращения: 28.08.2019)

3. Финансовая отчетность ПАО «Газпом» 2018 г. URL: https:/www.gazprom.ru/f/posts/72/692465/gazpromfinancial-report-2018-ru.pdf (дата обращения: 28.08.2019)

4. Статистическая отчетность об использовании результатов интеллектуальной деятельности. Роспатент. URL: https://rupto.ru/opendata/7730176088-usingipfedreg (дата обращения: 26.01.2020)

5. Гвозданный В.А. Влияние современной энергетики на развитие нефтедобывающей отрасли. URL: https:// bookonlime.ru/lecture/7-vliyanie-sovremennoy-energetiki-na-razvitie-neftedobyvayushchey-otrasli (дата обращения: 26.01.2020)

6. Юрков Д.В., Колесникова Ю.С., Фахрутдинов Р.М. Методология определения уровня нематериального развития региона//Вестник экономики, права и социологии. 2018. № 4. С. 105-109.

7. Составлено авторами на основе проделанных расчетов 